\title{
The Constitutionality of the Webb-Kenyon Bill
}

The so-called Webb Bill," "an act divesting intoxicating liquors of their interstate character in certain cases," was passed by Congress the latter part of February. President Taft, however, refused his approval, on the ground of its being "a violation of the interstate commerce clause of the Constitution, in that it is in substance and effect a delegation by Congress to the States of the power of regulating interstate commerce in liquors, which is vested exclusively in Congress." This view was concurred in by Attorney General Wickersham, who, in a lengthy opinion, submitted to the President and transmitted by the latter to Congress also held that the act was unconstitutional. The measure became law without the signature of the President, repassing the Senate on February 28 and the House of Representatives the next day. ${ }^{3}$ It is the purpose of this paper to determine the correctness of the administration's view that the law is unconstitutional.

The "original package" decision in Leisy v. Hardin" held that persons engaged in interstate commerce had the right not only to transport intoxicating liquor into prohibition States, but to sell it there in unbroken packages. The power of the States to enforce their local regulations was thus seriously interfered with; and this led to the passage of the

1 S. 4043, 62d Cong., 3d Sess. It was introduced in the House by Mr. Webb and in the Senate by Mr. Kenyon. For the purposes of this paper, it will be called the "Webb Bill."

2 Message of the President. Cong. Rec. Feb. 28, 1913, p. 4457.

3 Cong. Rec. pp. 4465 and 4509 . The vote in the Senate was 63 to 21 and in the House 246 to 95 .

4 (1890) 135 U. S. 100. 
Wilson Act of 1890,5 which provided that "all fermented, distilled or other intoxicating liquors or liquids transported into any State or Territory or remaining therein for use, consumption, sale or storage therein, shall upon arrival in such State or Territory be subject to the operation and effect of the laws of such State or Territory, enacted in the exercise of its police power, to the same extent and in the same manner as though such liquids had been produced in such State or Territory, and shall not be exempt therefrom by reason of being introduced therein in original packages or otherwise."

The Wilson Act was upheld, not on the basis of Congress having the power to delegate to the States the authority to regulate interstate commerce in this particular instance, for, as the Court said: "Congress did not use terms of permission to the State to act, but simply removed an impediment to the enforcement of State laws in respect to imported packages in their original condition, created by the absence of a specific utterance on its part. It imparted no new power to the States not then possessed, but allowed imported property to fall at once upon arrival within the local jurisdiction."

Later construction of the Wilson Act greatly destroyed its effect. The Supreme Court held" that the words "upon arrival" applied not to State lines, but when the shipments reached the consignee. The sale of liquor in the original package could, therefore, be forbidden, but the authority of the State could not attach before the liquors reached the parties to whom they were sent.

5 Act of Aug. 8, 1890, ch. 728, 26 Stat. Ir. 313. In Bowman v. Railroad, 125 U. S. 465,485 , the Court had said that "transportation of commodities between the States shall be free, except where it is positively restricted by Congress itself, or by the States in particular cases by the express permission of Congress." In Leisy v. Hardin, the doctrine outlined was that "so long as Congress does not pass any law to regulate it [interstate commerce], or allowing the States to do so, it thereby indicates its will that commerce shall be free and untrammelled." It is interesting to note that this reasoning was not exactly followed by In Re Rahrer, (1891) 140 U. S. 545, which upheld the Wilson law. See infra.

${ }^{6}$ In $\operatorname{Re}$ Rahrer, (1891) 140 U. S. 545.

${ }^{7}$ Rhodes v. Iowa, (1897) 170 U. S. 412. 
The prohibition interests almost immediately began a campaign for more effective legislation. For a time, however, doubt as to the constitutionality of the proposed measures, and other reasons prevented their passage. Hearings were held before several committees which considered numerous bills, ${ }^{8}$ all designed to accomplish the same purpose, to subject shipments to the police power of the State as soon as they crossed its borders. The result, after much debate and several amendments, designed to obviate constitutional difficulties which the advocates of the legislation admitted had to be met, was the Webb Bill. It is as follows:

"An act (S. 4043) divesting intoxicating liquors of their interstate character in certain cases.

"Be it enacted, etc. That the shipment or transportation in any manner or by any means whatsoever, of any spirituous, vinous, malted, fermented or other intoxicating liquors of any kind from one State, Territory, or District of the United States . . . . into any other State, . . . or from any foreign country into any State . . . . which said . . . . liquor is intended, by any person interested therein, to be received, possessed, sold, or in any manner used, either in the original package or otherwise, in violation of any law of such State, Territory, or District of the United States . . . . is hereby prohibited."

Much misapprehension and irrelevant discussion has been caused, it seems to me, by the fact that the title of the bill is misleading, and that other acts of a different character, (while aiming at the same end), have been considered, and the arguments holding them unconstitutional have been applied to the $\mathrm{Webb}$ legislation. President Taft himself seems to have been guilty of this mistake. In his message he quotes with approval the conclusions of Senator Knox, who, as chairman

8 See 59th Cong. 2d Sess. House Document 522; 61st Cong. 1st Sess. Senate Document 146; Hearings before Subcommittee of Judiciary com., U. S. Senate, 1912; Hearings before House Committee, 1912. 
of the Judiciary Committee, filled a report against several bills upon which hearings had been held.'

These bills, however, provided that interstate shipments of liquor should "upon arrival within the boundaries of such State or Territory, before or after delivery, be subject to the operation and effect of the laws of such State and Territory enacted in the exercise of its police power.... and shall not be exempt therefrom by reason of being introduced in original packages or otherwise." 10

That the Webb Bill presents different questions is evident. The first which must be considered is the general power of Congress over interstate commerce.

The Lottery decision ${ }^{11}$ is the leading case on the power of Congress to prohibit interstate commerce. In it, the Court said:

"If a State, when considering legislation for the suppression of lotteries within its own limits may properly take into view the evils that inhere in the raising of money in that mode, why may not Congress, invested with the power to regulate commerce among the several States. provide that such commerce shall not be polluted by the carrying of lottery tickets from one State to another? - We should hesitate long before adjudging that an evil of such appalling character, carried on through interstate commerce, cannot be met and crushed by the only power competent to that end."

$961_{\text {st }}$ Cong. 1st Sess. Sen. Doc. 146, p IX. Senator Knox's conclusions were:

"First. Interstate shipments are not completed until they reach the consignee.

"Second. An interruption or interference with interstate shipments before they reach the consignee constitute a regulation of commerce.

"Third. Regulating interstate shipments is an exclusive function of Congress.

"Fourth. Congress cannot delegate any part of its exclusive power to the States."

It is Senator Knox's third conclusion, which, as we shall see, is faulty when applied to the Webb Bill. It was perfectly valid, however, for the bills then being considered.

10 There were five bills before the Committee. Barring slight differences in phraseology, they were practically the same as the one quoted. The most discussed bill was introduced in the House by Mr. Sheppard and in the Senate by Mr. Kenyon, and commonly known as the "Sheppard-Kenyon Bill."

11 Champion v. Ames, (1902) 188 U. S. 321. 
On the same theory adulterated food has been excluded from interstate commerce, ${ }^{12}$ and in this class of res prohibitae Congress has put falsely labelled food, obscene literature, explosives, diseased cattle, game killed in violation of State laws, and numerous other articles. ${ }^{13}$

The most recent of all prohibitions is contained in the Mann Act, which makes criminal the transportation of women in interstate commerce for immoral purposes, or the obtaining, aiding or inducing of the transportation. ${ }^{14}$ That this was a valid exercise of the power of Congress to regulate interstate commerce was declared in the recent case of H.oke v. United States. ${ }^{15}$

But there are those who, recognizing this plenary power of Congress to interdict the shipment of certain commodities which "pollute" interstate commerce or which are deleterious to the health, hold that the liquor traffic is a legitimate business, and cite the decision in Louisville \& Nashville R. R. Co. v. Cook. In this case it was said:

"By a long line of decisions, beginning even prior to Leisy v. Hardin, it has been indisputably determined:

"a. That beer and other intoxicating liquors are a recognized and legitimate subject of interstate commerce.

"b. That it is not competent for any State to forbid any common carrier to transport such articles from a consignor in one State to a consignee in another."16

One of the strongest of the early expressions on the power of the States to regulate the internal traffic in intoxicating liquors was that of Chief Justice Taney, who said:

"If any State deems the retail and internal traffic in ardent spirits injurious to its citizens, and calculated to produce idleness, vice, or debauchery, I see nothing in the Constitution of

12 Hippolite Egg Co. v. United States, (1910) 220 U. S. 45.

13 For a partial list of instances where Congress has exercised its power of exclusion, the reader can see Cong. Rec. Feb. 18, 1913.

1436 Stat. I. 825, ch. 395.

15 Oct. Term, 1912. No. 381. Decided Feb. 24, 1913.

${ }^{16}$ Louisville, etc. v. Cook, (1912) 223 U. S. 70. 
the United States to prevent it from regulating and restraining the traffic or prohibiting it altogether, if it thinks proper." ${ }^{\prime 27}$

And in Mugler v. Kansas, ${ }^{18}$ the Court said:

"If, therefore, a State deems the absolute prohibition of the manufacture and sale, within her limits, of intoxicating liquors for other than medical, scientific and manufacturing purposes, to be necessary to the peace and security of society, the courts cannot, without usurping legislative functions, override the will of the people as thus expressed by their chosen representatives. They (the courts) have nothing to do with the mere policy of legislation."

Even stronger is the language in Crowley v. Christiansen $:^{19}$ "The statistics of every State show a greater amount of crime and misery attributable to the use of ardent spirits obtained at these retail liquor saloons than to any other source. The sale of such liquors has therefore been, at all times, by the courts of every State, considered the proper subject of legislative regulation . . . . The police power of the State is fully competent to regulate the business, to mitigate its evils or to suppress it entirely. There is no inherent right in a citizen to thus sell intoxicating liquors by retail; it is not a privilege of a citizen of the State or of a citizen of the United States. As it is a business attended with danger to the community it may, as already said, be entirely prohibited or be permitted under such conditions as will limit to the utmost its evils."

There is no inconsistency in these decisions. Prior to the passage of the Webb Bill, all intoxicating liquor was a legitimate subject of interstate commerce, subject to the power which the States possess under the Wilson Act. But so were lottery tickets before the statute which was upheld in Champion v. Ames. Before the Pure Food Law was passed, the courts would have said that anyone could send adulterated products

17 License Cases, (1847) 5 Howard, 504. See also Bartmyer v. Iowa (1873) 18 Wall. 129; Boston Beer Co. v. Massachusetts, (1877) 97 U. S. 25, 33, and Foster v. Kansas, (1884) 112 U. S. 201, 206.

18 (1887) 123 U. S.623, 662.

19 (1890) 137 U. S. 86, 91. 
through interstate commerce. Before the White Slave Act, the transportation of women for immoral purposes was permissible.

The decisions last quoted, which uphold the police power of the States to regulate the manufacture and sale of intoxicating liquor, are certainly evidence that this would be classed with lotteries and adulterated food. Our conclusion then is, that "an evil of such appalling character, carried on through interstate commerce," could be met and crushed by a power competent to that end,-that a federal law forbidding the transportation of all liquor would be constitutional.

But the Webb Bill is not this. It prohibits interstate shipments only when they are intended "to be received, possessed, sold, or in any manner used . . . . in violation of any law of such State." Congressman Webb puts the case thus:

"If Congress has the power to prohibit any shipment in interstate commerce of any liquors without assigning any reason whatever, I contend that Congress has the right to prohibit the shipment of any portion of that commerce, with or without reason, because the larger power controls the smaller and the smaller is involved in the larger. I contend that if our first premises are right, that we have constitutional power to pass this kind of a measure."20

Such a statement is obviously not that of a constitutional lawyer, but is the contention a correct one? The prohibitions of interstate commerce have, almost without exception, been directed against articles, the inherent character of which was objectionable. In only one important instance has this rule been departed from,- when in the "commodities clause" of the Hepburn Interstate Commerce Act of 1906, Congress forbade railroads to transport commodities (other than lumber) which they own, but such a prohibition has little if any bearing on the law, the validity of which is under discussion. ${ }^{21}$

${ }^{20}$ Hearings before Senate Committee, 62d Cong. 2d Sess., p. 90.

${ }^{21}$ See U. S. v Delaware Hudson Co., (1909) 213 U. S. 366 . The clause was necessary to prevent a carrier "engaged in interstate commerce from buying and selling a commodity which it carried, in such a way as to frustrate the provisions of the act" requiring that no discrimination be made in the rates charged. See New Haven $R$. R. v. Interstate Commerce Commission, (1906) 200 U. S. 361. 
The objection can thus be made that Congress has not legislated with regard to the character of the liquor; that there is no difference between a shipment intended to be sold in a "dry" State and one which is to be sold according to law. Concede that Congress has the power to exclude all intoxicants from interstate commerce or the smaller power of interdicting adulterated or impure liquor, and it does not follow, the objection goes, that the present discrimination is justifiable. ${ }^{22}$

It would seem, however. that such a contention is purely formal and that the power of Congress over interstate commerce is sufficiently comprehensive to include a prohibition such as that contained in the Webb Bill. In fact the right to exclude on account of intent seems to have been settled by the recent cases upholding the Mann Act. ${ }^{23}$ This, as already pointed out, forbids the transportation of women for immoral purposes and provides penalties for its violation. The Mann Act excludes certain women, just as the Webb Bill excludes certain liquors; and in both cases intent is controlling as to whether the transportation is forbidden. In the Hoke case, the Court said:

"There is unquestionably a control in the States over the morals of their citizens, and, it may be admitted, it extends to making prostitution a crime. It is a control, however, which can be exercised only within the jurisdiction of the States, but there is a domain which the States cannot reach and over which Congress alone has power; and if such power be exerted to control what the States cannot, it is an argument for-not against-its legality.

"The principle established by these cases is a simple one, when rid of confusing and distracting considerations, that Congress has power over transportation 'among the States;' that the power is complete in itself, and that Congress as an incident to it, may adopt not only the

22 By the Act of June 29, 1906, (34 Stat. I. 838), interstate carriers are permitted to give passes to certain persons and forbidden to give them to others. While Mr. Jefferson was President, Congress passed a law forbidding the transportation of free negroes from one State into any other State where they were not permitted by the laws of the States to reside. (2 Stat. I. 295, Act of Feb. 28, 1803.) These, however, are only partially analogous prohibitions.

23 Hoke v. U. S. supra. 
means necessary but convenient to its exercise, and the means may have the quality of police regulations."

But there is a difference between the Mann Act and the Webb Bill. The former definitely says that women destined for immoral purposes are excluded from interstate commerce. The latter depends on State law to say whether the intent is such that the shipment is prohibited, and the States will enforce the penalties. Their laws change from time to time; the Webb Bill looks not only to the present but to the future, and there may be forty-eight different sets of regulations, the intent to violate any one of which will ban the shipment from interstate commerce.

The question now is whether this distinction is controlling. There appears to be no reason why it should be. Instances of the adoption of State laws by the United States are frequent and embrace both enacted and potential legislation. Referring to the Judiciary Act of $1789^{24}$ which provided that the "laws of the several States . . . . shall be rules of decision in trials at common law in the Courts of the United States in cases where they apply," the Federal Court said:

"The words of this section are general, so as to include, as well the laws of the respective States which might thereafter be passed." 25

There thus seems to be no valid objection to the potential character of the State legislation and the inevitable expansion of the scope of the Webb Bill which will come as a consequence of more States adopting prohibition measures. That the enforcement of the Webb Bill would impair the obligation of the contracts relating to the shipment of liquors into "dry" territory, cannot be seriously maintained in view of the decisions of the Supreme Court on the Sherman Anti-Trust Act. Such contracts, moreover, would be made for an immoral purpose and that the purchase price may not be collectible is an incident of a hazardous business which is being legislated against by the States and by Congress. ${ }^{28}$

24 Act of Sept. 24, 1789, ch. 20, sec. 34, 1 Stat. L. 73.

${ }^{25}$ Golden v. Prince, (1814) Fed. Cas. No. 5,509, p. 542, 543.

${ }^{26}$ See infra for other instances of legislation by Congress. 
Under the Webb Law, offenders will be charged, not with the violation of it, but with the violation of State enactments. The theory, then, is that liquor, intended for use contrary to State rules, will be an outlaw of interstate commerce, and so the plea cannot be raised that the State, in having its authority attach as soon as the shipment reaches its borders is interfering with interstate commerce, because the right of being shipped between the States is denied by Federal legislation.

The sponsors for the bill and the lawyers who argued before the House and Senate Committees in its behalf, made, it seems to me, little effort to distinguish between the principles outlined above and those which were illustrated by the Wilson Act and the decision of the court upholding it. There seemed to be no effort to differentiate between the other bills and the one which was finally passed. ${ }^{27}$ And yet this difference, especially in the light of the Mann Act, is important if not controlling. Senator Hoar pointed it out as far back as 1890, when in the debate on the Wilson Bill, he said ${ }^{28}$

"Congress may say the power to engage in interstate or international commerce shall not be understood as permitting anybody to sell opium or intoxicating liquors to anyone else, and that they shall be excluded altogether from the domain of interstate commerce. That Congress has a right to say . . . . That is not a question of delegated power. It is not a question of permission to the State. It is a question of the right of Congress to prescribe what shall be the limit of interstate commerce." ${ }^{29}$

There is no question but that the Webb Law, if valid, will to a very considerable degree, enlarge the powers of the States. It will then be possible to interfere with shipments before they reach the consignee. In fact, once admit the constitutionality of the Webb Bill, and you must necessarily admit the validity of State legislation to the same effect. Thus, a State law, forbidding the importation of liquor intended to

27 The one exception is the excellent argument by Fred S. Caldwell, Oklahoma City, Okla. See Senate Hearings, 1912, p. 130.

2821 Cong. Rec. p. 4963.

${ }^{29} \mathrm{It}$ is interesting to note that this was some time before the Lottery decision. 
be used in violation of local regulations, would probably be valid. The authority of the State could not, however, in cases where there was no intent to violate the law, be attached to shipments before they reached the consignee.

The case of Louisville \& Nashville R. R. Co. v. Cook, ${ }^{30}$ referred to above, was one in which the Supreme Court held unconstitutional in so far as it concerned interstate commerce, a Kentucky statute which said that no liquor should be shipped from a "wet" county to a "dry" one. It was, however, a valid exercise of the police power to apply such a regulation to intrastate commerce. The Webb Bill would seem to make this law apply to interstate shipments as well, since transportation into Kentucky with intent to pass from "wet" into "dry" territory would be with intent to violate the State law.

Another conspicuous example of a State's increased power is illustrated by the so-called "search and seizure" law recently passed by North Carolina. ${ }^{31}$ This makes the "possession of more than one gallon of spirituous liquors at any one time" prima facie evidence of the provision "that it shall be unlawful for any person or firm . . . . to have in his . . . . possession, for the purpose of sale, any spirituous, vinous, or malt liquors." 32

This law also provides that the intoxicants, when found in forbidden amounts, may, upon warrant, be seized and kept "subject to the orders of the court." So far as interstate commerce is concerned, the execution of this law would not appear to raise any constitutional difficulties, if the Webb Bill is valid, for under the Federal statute, the shipment into the State to anyone except licensed druggists of liquor in more than the stated quantities would be with intent to violate the law and would be forbidden. ${ }^{3 s}$

30 (1912) 223 U. S. 70.

31 Ratified March 3 and in force from April 1, 1913.

32 Different quantities are specified for vinous and malt liquors.

33 Other possible constitutional difficulties are not here considered. North Carolina is, I believe, the first State to pass such drastic legislation, making the possession a crime. The point made here is that shipments which would violate this law are forbidden, and that the State, without interfering with interstate commerce, can seize the liquor in transit. 
On the other hand, the Delaware Law of April 8, 1913, forbids the shipment of liquor into local option territory and makes it unlawful for any person "to carry any quantity of spirituous liquor from any point within the State of Delaware into local option territory within said State greater than one gallon within the space of twenty-four hours." The first section of this, even under the Webb Bill, seems to me to be invalid. The Kentucky statute, just considered applies to shipments from county to county, within the State. Here, then, is the test which must be met: Is the shipment with intent to violate a valid State law? If so, it is barred from interstate commerce; the State can act, even to the extent of forbidding its importation, and there is no usurpation of the Federal authority to regulate intercourse among the States.

To the extent that the Webb Law has enlarged the powers of the States, narrowly speaking, it constitutes a delegation of power. But to sustain it, casuistical reasoning like that used to justify the Wilson Act is not necessary. It is a delegation not in language, but in effect. Congress has not given permission. It has not acted on the States, but on things. The forbidden shipments would not be interstate commerce and so there could be no unconstitutional interference by the States. ${ }^{34}$

Much of the argument against the constitutionality of the Webb Bill was directed against certain provisions which were later left out. In its original form, clauses were included which declared that the authority of the State should attach when the boundary lines were reached. The validity of this provision would seem to be in serious doubt. By it, the States would, in words, have been granted the power to interfere with legitimate interstate commerce, since the decisions had been to the

34 "A State has power to regulate the introduction of any article, including a food product, so as to insure purity of the article imported, but such police power does not include the total exclusion of an article of food." Schollenberger v. Pennsylvania, (1898) 171 U. S. 1. It would seem that this reasoning might well apply to intoxicating liquors, but the answer is that in the latter case no element of fraud is involved. The States of course can exclude diseased cattle, obscene literature and lottery tickets, for the reason that these are outlaws of interstate commerce. 
effect that "upon arrival" meant upon delivery to the consignee. There were, in addition, certain clauses in the original bill which declared "contracts pertaining to such transactions null and void," and that "there shall be no property right in any such liquor while in the possession of" a carrier in violation of the preceding provisions. Vigorous objection was made on the ground that this gave a State statute an extra-territorial effect, and it would seem that this was the case. As the Bill now stands, of course, this difficulty was done away with. No State could take proceedings in rem and no action would lie until the borders of the State had been passed. ${ }^{35}$

Finally, it remains to mention what, it is claimed, is a precedent for the legislation under discussion. The so-called Lacy Act of $1890^{36}$ forbids the transportation from a State of game killed in violation of local laws. The Act provides penalties, but its primary purpose is to enable the States to enforce their local game regulations. It was before a Federal Circuit Court and was held to be constitutional, ${ }^{37}$ the Court basing its opinion on Geer v. Connecticut. ${ }^{38}$ This case was one which upheld a statute of Connecticut forbidding the transportation, or possession with intent to transport, of certain kinds of game from the State. The opinion traced the theory of ferae naturae in all systems of law, and that the statute was not an interference with interstate commerce was held to be the case because the State was owner of its game, and could make regulations to preserve it for the common use as it saw fit. The reasoning in the Rupert case, is not conclusive, but the presumption is that the Lacy Act would be held constitutional. The doctrine of ferae naturae and the fact that transportation from a State is forbidden make the analogy an imperfect one. ${ }^{39}$

35 It is interesting to note that in his brief, submitted to President Taft, Attorney General Wickersham quotes from Senator Root several arguments against the constitutionality of the sections which were left out. Record p. 4460.

${ }^{36}$ Criminal Code. Act of March 4, 1909, Sec. 242.

37 Rupert v. U. S., (1910) 181 Fed. 87.

38 (1896) 161 U. S. 519.

39 In Siltz v. Hesterberg, (1908) 211 U. S. 31, it was held that it is not a regulation of foreign commerce, when the possession of certain kinds of game during the closed season is forbidden, even though the game might have been lawfully taken in foreign countries during the 
Our conclusions, then, are briefly:

(1)-That Congress, having plenary control over interstate commerce has the power to pass a law forbidding all shipments of intoxicating liquors, and

(2)-That it is a valid exercise of this power to use only a part of it, and to enact that intoxicants intended to be used in violation of State law are denied the privileges of interstate commerce;

(3)-That the changing laws of forty-eight States offer no sound objection to the validity of the legislation;

(4) - That the Webb Law delegates no power to the States, and does not in terms, give them permission to act; that it merely makes certain shipments outlaws of interstate commerce, so that the owner or carrier cannot rely on the defense that the police power of the State is interfering with a subject exclusively under Federal control, and finally,

(5)-That the law will be sustained for the reasons given, and because any other contention would "confound things important to be distinguished" in that it would urge "a right exercised in morality to sustain a right to be exercised in immorality." And this, the court has said, is a "supreme fallacy." 10

\section{LINDSAY ROGERS.}

Johns Hopkins University, Baltimore, Maryland.

open season there. In construing the State statute which forbade possession, the New York Court of Appeals said that the Lacey Act was congressional assent to the passage of laws within the limits laid down in Rahrer's case. The Supreme Court, however, held that it was not necessary to consider the Lacey Act in order to justify the New York statute.

See the article by James D. Barnett on "The Delegation of Legislative Power by Congress to the States," 2 American Political Science Review, p. 347 for an illuminating discussion of problems upon which Congress has permitted the States to legislate. This whole question as Mr. Barnett points out, is exceedingly complicated, and no one rule can be laid down.

to Hoke v. U. S., supra. Sec. 217 of the Criminal Code, Act of March 4, 1909, declares spirituous liquors non-mailable. Sec. 238 forbids delivery to anyone but the bona-fide consignee, and Secs. 239 and 240 make criminal C. O. D. shipments, agency on the part of the carrier, or false marking of packages containing liquor. These offenses are thus dealt with by Federal enactment and the efficacy of the Webb Law would seem to be more certain. 